\title{
SERES FÍSICOS: ESTEREÓTIPOS, ESPORTE E A EDUCAÇÃO FÍSICA DOS MAORI NA NOVA ZELÂNDIA ${ }^{1}$
}

\author{
Brendan Hokowhitu \\ University of Otago, Dunedin, New Zealand
}

\begin{abstract}
Resumo:
Este trabalho examina como o esporte, a educação pública e a educação física têm contribuído para a supressão dos indígenas maori da Nova Zelândia pela promoção de estereótipos desse povo como seres físicos e pouco inteligentes. O artigo começa por fornecer uma genealogia histórica do estereótipo físico e selvagem maori. Em seguida, apresenta-se como este estereótipo é usado para justificar um sistema de educação racista que canalizou os maori a atividades manuais, em oposição a áreas acadêmicas. Mais tarde, foi oferecida inclusão à cultura maori somente dentro de domínios não ameaçadores, como a educação física e os desportos. As ramificações da Educação Física se tornaram a primeira a oferecer aberturas aos maori. Finalmente, eu sugiro que a naturalização dos maori como esportistas contribui para o processo de assimilação maori numa área que destaca sua supostamente inerente fisicalidade.
\end{abstract}

Palavras-chave: Esporte. Nova Zelândia. Indígenas. História.

\section{Introdução}

O escritor os modifica de forma que eles possam ser explorados de forma mais eficaz pelo administrador. A exploração é a realidade por trás da retórica. (MANGAN, 1993, p. 9)

E ste estudo examina como o esporte, a educação pública e a Educação Física contribuíram para a supressão dos indígenas maori da Nova Zelândia2. Ele demonstra que os vestígios históricos da sel-

1-Publicado originalmente em Culture, Sport, Society, vol. 6. n. 2/3, p. 192-219, 2003. Traduzido com autorização do autor pelo Centro de Excelência Empresarial Ltda-Me (Cetur). Revisão: Tadeu João Ribeiro Baptista.

2-A palavra maori é plural e singular, assim, alguém pode dizer "Bob é um maori", enquanto outro pode dizer, "aquelas crianças são maori". Não existe "s" na língua 
vageria e dos aspectos físicos maori foram perpetuados através de um sistema racista de educação pública, limitando as conquistas maori e a integração da tikanga Māori (cultura maori) nas arenas físicas, tais como o esporte e a Educação Física. $\mathrm{O}$ artigo começa examinando a base histórica do estereótipo dos maori como um povo físico, particularmente a forma pela qual o controle do poder/conhecimento pelo colonizador combinou a superioridade racial e o Darwinismo social para construir a cultura maori como confinada a um mundo físico primitivo. Como explicarei posteriormente, esta história ajudou a encontrar um sistema de educação racista que, ao denegrir a cultura maori, justificou a extinção de suas práticas corporais3. Mais tarde, o Estado utilizou o estereótipo da fisicalidade maori para canalizá-los nos campos físicos, em oposição às esferas acadêmicas da vida. Uma mudança de atitude ocorreu nos anos entre guerras; a Educação Física pública se tornou a primeira área a fazer propostas inclusivas aos maori. Ao analisar esta mudança mais de perto, concentro-me em Philip Smithells, o Reitor da Escola de Educação Física da Universidade de Otago, em Dunedin. Smithells colocou a tikanga Māori no currículo da Educação Física na Nova Zelândia, mas, discutivelmente, suas tentativas de inclusão cultural oprimiram ainda mais os maori, perpetuando seus estereótipos. Por fim, o artigo desconstrói as representações dos maori

maori e é correto empregar "maori" como forma plural. Eu evito empregar a expressão "o maori" porque isso sugere que os maori são ou eram um grupo homogêneo, o que claramente não o é. Maori é uma palavra genérica que inicialmente significava "normal", mas tem sido incorretamente empregada para representar povos indígenas nas ilhas Pacíficas, chamadas agora Nova Zelândia. Mason Durie diz isso sobre ser maori: "Antes do contato com o europeu, a palavra Maori simplesmente significava normal ou usual. Não havia o conceito de uma identidade Maori no sentido de uma similaridade cultural ou nacional [...] Os habitantes originais da Nova Zelândia não se referiam a si mesmos como Maori. Ao invés disso, qualquer uma das 40 ou mais tribos eram Rangitãne, Ngãti Apa ou Tuhoe". (DURIE, M. Te Mana, Te Kãwanatanga: the politics of Mãori Self-Determination. Auckland: Oxford University Press, 1998, p. 53)

3-Nota do Revisor (NR): Apesar de o termo usado pelo autor em inglês ser "physical", literalmente, físico, como ele denota o termo práticas ou prática, entendemos que a compreensão mais adequada seria a de práticas corporais, pois, em que pese o dissenso na literatura especializada brasileira, o termo, assim mesmo, parece mais adequado do ponto de vista cultural. 
como naturalmente atléticos. $\mathrm{O}$ artigo conclui que a naturalização dos maori como desportistas contribuiu para o processo de colonização, assimilando-os de uma forma bastante limitada; os maori são bem-sucedidos somente nas áreas da sociedade que não ameaçam sua representação dominante como um povo físico.

\section{Histórico}

As representações raciais "precisam ser honestamente localizadas em relação às interpretações contestadas de poder", nas quais o poder "funciona através de procedimentos disciplinares e auto-regulatórios da vida diária" (CORNWALL, 1994, p. 37-38). Como o filósofo francês Michel Foucault pergunta: "Se o poder nunca apresentou nada além de seu caráter repressor, se nunca fez nada além de dizer não, você realmente acredita que devemos obedecê-lo?" (FOUCAULT, 1977, p. 36). Em outras palavras, os ideais raciais dominantes e outras construções sociais são poderosos por serem normas disciplinadas as quais o indivíduo está disposto a cumprir ou a obedecer. A autoridade final do poder, Foucault observou, não estava em sua forma monolítica ou repressiva, mas em seu poder de disciplinar através da construção, isto é, criar uma representação "normal" de uma pessoa com base nas construções históricas de raça, classe, gênero e idade. Tais representações "normais" dos maori são, sem dúvida, relacionadas a um histórico biorracista projetado pelo privilégio do colonizador, conforme Sue Tait (1999, p. 207) destaca:

Representações dos corpos negros permanecem entalhadas com as fantasias e ansiedades de nossas histórias racistas [...] assume-se que a biologia seja responsável não somente pelas variações físicas como a cor da pele, mas também pelas qualidades como a inteligência, comportamento e capacidade [...] há vestígios de suas suposições - por exemplo, o instinto de um guerreiro "no sangue" [...] ou habilidade esportiva ou muscular entre os negros devido ao "ritmo natural".

O racismo nas colônias não se desenvolveu devido à simples ignorância ou ódio de uma cultura divergente; na verdade emergiu uma vez que a colonização foi justificada através de discursos sobre a raça e o direito de comandar dos europeus (BEDERMAN, 1995). As dife- 
renças biológicas entre as raças confirmaram a estrutura do poder natural do colonialismo: "[Europeus] gostavam de ver a colonização como uma declaração moral sobre a superioridade das [suas] culturas e a inferioridade das outras" (NANDY, 1983, p. 100). Viajantes, missionários e antigos colonizadores definiram os maori como um povo físico, selvagem e desprovido de inteligência (SMITH, 1993, p. 8-10). As representações dos maori e pakehas (o nome comum dos neozelandeses com ancestrais europeus, significando, literalmente, "estrangeiros") se tornaram "ícones de representação" que refletiram a relação de poder entre os dois e, invariavelmente, resultou em "um vocabulário apropriado e um conjunto de imagens verbais representando diferenças significativas [...] figuras estilizadas ao invés de pessoas reais foram criadas" (MANGAN, 1993, p. 8-10). Uma configuração estilizada dos maori foi o tolo físico, desprovido de inteligência. Uma dicotomia física/intelectual, que limitaria os maori por toda a história colonial, emergiu na grande era colonizadora dos séculos dezoito e dezenove. A noção do século dezoito de "Outro" primitivo derivou da ideia da "Grande Corrente do Ser": a crença de que Deus havia criado todas as coisas vivas e as organizado em uma hierarquia de existência (MILES, 1989). Conforme o século dezenove se aproximou, as teorias do Iluminismo, do progresso da raça humana e a teoria da evolução correspondente deram crédito ao conceito da divisão racial hierárquica. A aplicação da teoria da evolução para explicar a disparidade de poder entre as raças produziu o darwinismo social. O darwinismo social forneceu evidências científicas para fragmentar o continuиm humano em uma hierarquia de raças. A ciência validou diferenças arbitrárias entre os europeus e os outros; raças se tornaram fatos com base nas "diferenças primeiramente naturais e biológicas que eram inerentes e inalteráveis" (MILES, 1989, p. 70).

No contexto da Nova Zelândia, o darwinismo social validou as afirmações do senso comum de que os maori eram menos inteligentes do que os colonizadores avançados: "O poder econômico e britânico [...] [foi] uma indicação da "sobrevivência do mais apto"” (SIMON, 1990, p. 56). Além disso, o darwinismo social estava bastante relacionado com a crença de uma dicotomia natural entre os maori e os europeus civilizados: os maori pertenciam ao império físico inconsciente, enquanto os europeus pertenciam ao império do Iluminismo ocidental. A reivindicação de Descartes (1996) de que a alma, incluindo a moral e a inteligência, era algo divorciado dos mecanismos materiais ou cor- 
porais, criou o dualismo cartesiano, mais tarde empregado para projetar os aspectos físicos das pessoas de cor como não iluminadas e, assim, não civilizadas. De acordo com Ernesto Laclau (1990), as pessoas colonizadas eram essencialmente desprovidas de história ou, em outras palavras, incapazes de ter o pensamento universal. Tradutores dos séculos dezoito e dezenove circularam a mitologia indígena no Ocidente, descrevendo-a como "contos de fadas irracionais produzidos por histórias inconscientes, feitas para selvagens e crianças" (NANDY, 1983, p. 60). Filósofos europeus como Hegel (1899, p. 204225) descreveram o Outro primitivo como possuindo geneticamente um "caráter de espírito em um estado de sonho", como incapaz de ação e, portanto, "pré-histórico" e por sua vez enfrentando o destino necessário da subordinação europeia.

Os missionários, viajantes e filósofos europeus retrataram os pensamentos e a cultura dos maori como primitivos: localizados em algum lugar entre aquele do europeu civilizado e do macaco enganoso, delirante e infantil (HOKOWHITU, 2002). Referindo-se ao poste visto num morere (balanço), o viajante William Wade (1997, p. 157) descreve "meninos e meninas, completamente nus e as mulheres somente com uma peça incompleta em volta dos quadris, subindo no poste tão rapidamente como macacos". Similarmente, Edward Wakefield, em 1845, acreditou que a paixão dos maori por contar histórias tinha toda a sensibilidade de um primata: "Nada pode lembrar alguém mais impetuosamente do macaco que observou o mundo do que um maori por meio das novidades contadas" (Apud. BEST, 1925, p. 120). Frederick Maning (1956, p. 44), em 1863, comparou o kapa haka (qualquer forma de dança acompanhada por canto ou entoação) a um "dança e bate" apresentado por "macacos loucos". Outros empregaram métodos "científicos" para demonstrar a falta de evolução da inteligência maori. Em seu The Story of New Zealand: Past and Present, Savage and Civilized, Arthur Thomson (1859, p. 81-84), um antigo viajante, explorou a craniometria para rebaixar a inteligência maori:

Foi determinado pela pesagem dos crânios [...] que as cabeças dos neozelandeses são menores do que as cabeças dos ingleses, consequentemente os neozelandeses são inferiores aos ingleses em relação à capacidade mental [...] A memória que eles possuem é a memória infantil; e suas mentes podem ser comparadas com espelhos [...] incapazes de reter qualquer traço do passado 
[...] A faculdade da imaginação não é fortemente desenvolvida entre eles, embora eles permitam que ela fique livre para acreditar em superstições absurdas [...] Esta análise mostra que os neozelandeses possuem mentes de crianças.

Um pākehā do início do século dezenove percebeu os maori como tendo a capacidade de alcançar eventualmente a "civilização". Na verdade, os maori eram geralmente chamados como os mais civilizados de todos os selvagens, ou como Jack Phillips coloca, os "maori arianos", um conceito sugerindo que os maori, de todos os povos indígenas, "eram os mais parecidos conosco" (Apud. SHICK; DOLAN, 1989, p. 56). Entretanto, dentro de algumas décadas, os maori seriam colocados como um obstáculo para o desenvolvimento social e econômico da nova colônia. A mudança na atitude ocorreu um pouco antes do início das Guerras da Nova Zelândia, principalmente quando a impaciência dos colonizadores com a recusa dos maori em vender suas terras chegou ao auge 4 . Desta forma, descobertas antropológicas e outras descobertas científicas apresentaram os maori cada vez mais como "inerentemente inferiores" (SIMON, 1990, p. 85). A genealogia resultante da representação destas imagens criou efetivamente acesso limitado dos maori aos privilégios desfrutados pelos pākehā. A próxima seção discute como, em primeiro lugar, a educação missionária empregou a aversão dos aspectos físicos dos maori para proibir as práticas culturais corporais deste povo; em segundo lugar, como a educação pública aplicou a naturalidade da fisicalidade maori para limitá-los a uma educação "física"; e em terceiro lugar por que a Edu-

4-Nota do editor (NE): Entre 1845 e 1872, aproximadamente, sucederam-se numerosos conflitos na Nova Zelândia, conhecidas, desde então, como as Guerras da Nova Zelândia. Basicamente, as disputas pela propriedade de terras foram o principal móvel desses conflitos. Em 1840, depois de longo período de conflitos entre tribos maori, quase sempre com a mediação ou mesmo a participação direta de estrangeiros (especialmente pescadores de baleia), mais de 500 chefes maori assinaram o Tratado de Waitangi, em que reconheciam o governo da Coroa britânica, ao mesmo tempo em que tinham reconhecidos seus direitos de propriedade sobre suas terras tradicionais. Apesar disso, no entanto, divergências a respeito do cumprimento do tratado geraram novas disputas, sobretudo depois de 1850 , quando se intensificou a colonização estrangeira da Nova Zelândia e foram descobertas jazidas de ouro.

Pensar a Prática, Goiânia, v. 15, n. 1, p. 1-271, jan./mar. 2012 
cação Física promovida pelo Estado foi vista como uma área de estudo apropriada para a inclusão incipiente do tikanga Māori.

\section{Educação missionária}

Em 1808, Samuel Marsden recomendou a construção de escolas missionárias para "uma nação que não obteve vantagens até agora do comércio ou das Artes da Civilização e, portanto deve estar em um estado de Escuridão e Ignorância Pagã, na qual todas as nações que não possuem conexão com a parte Civil Comercial e Religiosa da Humanidade devem estar irrevogavelmente" (Apud. HARVARD-WILLIAMS, 1961, p. 115). Assim, guiados pela intenção justa, os primeiros missionários, liderados por Marsden, chegaram em 1814 para substituir as instituições culturais maori pelas faculdades europeias civilizadas (SIMON, 1990). A filosofia de assimilação de Marsden encorajou os maori a adotarem as práticas costumeiras, morais e comerciais como "um preparo para receber o evangelho cristão" (SIMON, 1990, p. 51). Tal política era congruente com as crenças da maioria dos missionários que lamentaram os valores, atitudes e percepções dos maori e que, consequentemente, tentaram esmagar o tikanga Mãori. A educação missionária impôs aos maori uma forma alternativa de compreender o mundo. Por exemplo, Brian Sutton Smith sugere que a intervenção missionária impactou prejudicialmente os conceitos dos estudantes em relação à atividade física. De acordo com ele, enquanto os missionários baniram completamente diversos "jogos" maori, eles mostraram mais leniência em relação aos "passatempos que eles reconheceram como sendo passatempos de "civilizados" e não somente de crianças "pagãs". Assim, as crianças maori foram explicitamente encorajadas a continuar a jogar os jogos que eram "inteligíveis para o estilo de vida europeu" (SMITH, 1951, p. 319). No fim dos anos 1940, Sutton Smith descobriu jogos como knucklebones ${ }^{5}$, pernas de pau, peão e jogos com cordas em algumas comunidades maori, todos eles com "correspondentes nas brincadeiras desorganizadas das crianças Pākeh"̄" (SMITH, 1951).

O que Sutton Smith falhou em reconhecer é que os costumes culturais que acompanhavam tais práticas maori não sobreviveram aos ata-

5-NE: Espécie de jogo em que uma pedra (geralmente) é arremessada para o ar, enquanto apanham-se outras sobre o chão ou sobre a mesa.

Pensar a Prática, Goiânia, v. 15, n. 1, p. 1-271, jan./mar. 2012 
ques missionários. Por exemplo, os europeus viam a morte e a "brincadeira" como incongruentes, ainda assim os maori usavam pātaka tākiti (peões) e outras práticas nos contextos da morte e do lazer:

Quando um clã foi derrotado em uma batalha e os visitantes iam dar as condolências a eles, todos se juntavam na praça da vila e lá entoavam o lamento da morte. Na conclusão de cada parelha de versos da música, diversos peões eram jogados e estes se lamuriando ajudavam a vingar a derrota. (BEST, 1996, p. 161)

Muito provavelmente os maori associavam o pātaka tākiti à respiração: "Dizia-se que os peões murmurantes que continuavam girando por um tempo considerável tinham um grande fôlego, o que era considerado desejável" (BEST, 1976, p. 157). A inclusão de "jogos" no ritual espiritual pareceu bárbaro para os missionários cristãos, que os proibiram. Como um velho maori testemunhou: "ficamos bastante intrigados sobre as novas leis que fizeram para o nosso povo. Não deveríamos jogar os peões murmurantes aos domingos" (Apud. BEST, 1925, p. 15). Em 1839, o viajante americano Charles Wilkes (1845, p. 175) confirmou a reclamação do kaumātua (sábio idoso): "divertimentos sociais são proibidos por penalidades severas, embora as pessoas sejam evidentemente aficionadas por eles".

Em 1845, o missionário William Brown descreveu a dança e o canto maori, mas notou com orgulho que "entre os nativos missionários eles eram totalmente interrompidos" (Apud. BEST, 1925, p. 15). Timoti Kāaretu (1993) lamentou o efeito da política missionária em relação ao kapa haka, observando que diversas tribos o praticavam menos, conforme a influência dos missionários era intensificada. Da mesma maneira, o kapa haka se tornou obsoleto em algumas tribos. Por exemplo, em 1934, uma tribo teve que aprendê-lo de outra tribo para que eles pudessem receber as celebrações de Waitangi ${ }^{6}$.

O Estado não sancionou oficialmente as práticas missionárias antes de 1847, nem as fiscalizou. Os representantes britânicos viam a educação missionária dos maori como uma forma barata de controle social

6-Refere-se às celebrações de comemoração a assinatura do Tratado de Waitangi entre os maori e os pakehã. O Tratado de Waitangi é reconhecido como o documento fundador da Nova Zelândia [c.f. NE número 4].

Pensar a Prática, Goiânia, v. 15, n. 1, p. 1-271, jan./mar. 2012 
(MANGAN, 1993). Os políticos só aprovaram oficialmente a doutrina de civilização das escolas missionárias depois que a aceitação maori do movimento missionário começou a minguar. Inicialmente, diversos maori viram os assentamentos missionários como uma forma de obter certas habilidades (tais como alfabetização) ${ }^{7}$, necessária para lidar com o Pākehā. Mais ainda, a resistência maori (ou a "apatia", como era e é comumente descrita) em relação às escolas missionárias cresceu conforme os maori foram tomando consciência da repressão e constrição missionária de seus ensinamentos. A falha das escolas missionárias em converter a maioria dos maori eventualmente resultou na introdução da educação pública para os "nativos".

\section{A genealogia da educação pública}

Até 1867, os missionários forneceram toda a educação europeia dos maori. Os parlamentares que debateram em 1867 a Lei de Escolas Nativas claramente temeram que os maori que não eram educados pelos europeus tinham mais probabilidade de revolta contra as práticas coloniais. Henry Carleton, o Sub-Secretário do Departamento Nativo, insistiu que "o estilo de vida tradicional maori não poderia continuar a ser tolerado [...] as coisas chegaram num ponto que seria necessário exterminar os nativos ou civilizá-los" (SIMON, 1990, p. 102). Os debates parlamentares sobre a educação nativa dão mais ênfase à "assimilação das crianças maori na cultura e sociedade europeia" (HARKER; MCCONNOCHIE, 1985, p. 92) do que ao dever humanitário. Resumindo, a educação era vista como um agente de mudança social para os maori, o que beneficiaria a colônia. Em 1867, a Lei de Escolas Nativas colocou a educação maori sob a jurisdição do Departamento de Assuntos Nativos e substituiu as escolas missionárias por um sistema nacional de escolas diárias nas vilas maori.

Representações dos maori como selvagens deram forma à política de educação da Nova Zelândia. Como J. A. Mangan (1993, p. 10) diz, "a ideologia deu forma à ficção e a ficção, por sua vez, formou a ideo-

7-Para uma discussão sobre a alfabetização maori ver (SIMON, 1990). Por vários anos, alfabetizados maori excederam em número os alfabetizados europeus. Existem várias provas do aprendizado maori para escrita e leitura do inglês em poucos dias. Certamente, tais fatos são largamente desconhecidos, uma vez que eles não confirmam os estereótipos dominantes sobre os maori.

Pensar a Prática, Goiânia, v. 15, n. 1, p. 1-271, jan./mar. 2012 
logia". Os primeiros colonizadores retrataram a educação como parte de um dever evangélico para levar os maori para longe de sua cultura pagã, em direção à civilização moderna. A política educacional, portanto, foi construída sob um projeto de "doutrina moral projetada" (MANGAN, 1993, p. 11). Os colonizadores e o governo embrionário da Nova Zelândia esperavam que ao educar os maori, eles evitariam o que poderia acontecer no fim das contas se todo o resto falhasse - o extermínio (BARRINGTON; BEAGLEHOLE, 1974). Mais ainda, tais esperanças tiveram como base a satisfação dos liberais britânicos, cientes das atrocidades que haviam ocorrido em outras colônias, ao invés da empatia pelos nativos da Nova Zelândia. A discussão a seguir demonstra como a representação errônea da selvageria e da fisicalidade maori dentro dos discursos educacionais justificou inicialmente a educação pública dos maori.

\section{Reforçando os estereótipos}

Vocabulários dominantes moldam a forma com que os grupos de pessoas percebem umas as outras, com o resultado sendo uma interação que estabiliza o "mundo do dominante, tomado como certo" (ESLAND, 1971, p. 81). A educação imperial perpetuou as imagens raciais dos primeiros viajantes e propagou a teoria científica racista. Seu principal objetivo era "apropriar as atitudes da dominância e deferência [...] para moldar as regras em padrões de subserviência adequada a legitimar a inferioridade [...] desenvolvendo naqueles que estabelecem as regras, conviç̧ões sobre a benevolência e superioridade 'legítima' de suas regras" (MANGAN, 1993, p. 6).

A percepção da cultura maori como bárbara e, portanto, necessitando de uma educação civilizadora, aparece na seguinte citação de um parlamentar:

O "Haka" é uma exposição ao mal que realmente encontra-se na raiz da atual condição estagnada [dos Maori], uma exibição do substrato da total imoralidade, depravação e obscenidade que forma a base de sua raça; e ao invés da aparência atraente com a qual disfarçamos desastrosamente a madeira bruta, não devemos fazer nada até que alteremos todo o seu caráter, tomando em nossas mãos pela força a educação dos jovens em crescimento. (Apud. SIMON, 1990, p. 86) 
Os livros escolares da Nova Zelândia comumente contrastaram a superioridade da raça britânica com as raças mais fracas para alimentar o nacionalismo imperialista. Por exemplo, um texto geográfico registra que: "Os brancos formam de longe a raça mais importante, uma vez que possuem as melhores leis [e] a maior quantidade de aprendizado" (WARD, 1879, p. 44). As explicações-padrão das diferenças raciais as atribuíam à localização geográfica, à variação climática ou à quantidade de sangue branco. "Os trópicos criaram a indolência impotente [...] a localização e o alívio de regiões de temperatura particular [...] produziram sub-raças" (MCGEORGE, 1993, p. 67).

Imagens dos maori em livros escolares, próximo da virada do século vinte, regurgitavam fábulas familiares dos viajantes que tinham, em alguns casos, mais de 100 anos de idade. Os maori eram representados como agressivos: "No final eles avistaram a Ilha do Norte [...] Homens marrons bravos vieram a toda a velocidade com lanças para mandá-los de volta" (NEW ZELAND EDUCATION DEPARTMENT, 1908, p. 135). O mito que envolve os moriori das ilhas Chatam continuou a aparecer nos livros escolares nos anos $1920^{8}$. Os maori eram retratados como pessoas violentas cuja selvageria vinha de uma "raça mais escura e mais fraca" (MCGEORGE, 1993, p. 77). O mesmo mito ainda persiste entre a "barulheira dos pakehas reivindicando as terras dos maori” (MCGEORGE, 1993, p. 77). Os maori também eram representados como crianças inocentes, confusas ou desobedientes: "os maori tinham vários problemas e tentavam roubar qualquer coisa" (NEW ZELAND EDUCATION DEPARTMENT, 1908, p. 136); “eles achavam que as pessoas eram como crianças [...] homens de guerra se satisfaziam com colares de miçanga e bonecas [...] como crianças malvadas, os nativos roubavam e contavam mentiras e ameaçavam travessuras com lanças" (NEW ZELAND EDUCATION DEPARTMENT,

8-Os moriori eram uma tribo maori que vivia na costa da Nova Zelândia, nas ilhas Chatham. Entre 1790 e 1840 sua tribo foi devastada por doenças europeias, perda do fornecimento básico de comida por causa do extermínio de focas por caçadores europeus e assassinato pelas tribos invasoras taranaki. O mito sugere que os maori mataram uma raça escura e mais fraca pela terra, o que teria justificado a usurpação da Nova Zelândia pelos pãkehã (que é uma raça mais poderosa e iluminada). Na realidade, contudo, as tribos taranaki assassinaram apenas 226 moriori, enquanto os efeitos das ações dos europeus (como sobre todos os maori) sobre a morte dos moriori foi muito mais significativa. (WALKER, 1990, p. 39-42)

Pensar a Prática, Goiânia, v. 15, n. 1, p. 1-271, jan./mar. 2012

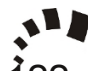


1908, p. 24-25). Os textos escolares retratavam a tikanga Māori como um mito fantástico. Os primeiros mitos, ainda os favoritos nas salas de aula de hoje em dia, foram apresentados como uma série de histórias de maori intituladas "Contos de Fadas da Maorilândia" (NEW ZELAND EDUCATION DEPARTMENT, 1908, p. 29).

$\mathrm{O}$ retrato mais comum dos maori, nas décadas seguintes à virada do século vinte, era o do "selvagem nobre". Uma vez que os maori sobreviveram a sua prevista morte natural ${ }^{9}$, a população de colonizadores se viu no meio de vizinhanças nativas. Os maori eram agora os bárbaros mais sofisticados. De acordo com a política de assimilação do dia, os maori da "nova era" pareciam capazes de realizar a maioria das funções dos pākehā. Os livros distinguiam de forma implícita os "maori reais" do passado e os "cidadãos de pele marrom" de hoje em dia. Os primeiros eram "guerreiros, poetas e caçadores românticos, mascarados e tatuados [...] os maori haviam feito tão bem para os selvagens que suas conquistas podiam ser comparadas com aquelas dos britânicos em um passado remoto" (MCGEORGE, 1993, p. 69), uma vez que eles demonstraram "uma maior aptidão para a civilização do que qualquer outra raça bárbara" (CORNEWLL, 1881, p. 330). A série de recursos educacionais amplamente utilizadas, Imperial Readers, declarou que "os maori eram selvagens, mas selvagens nobres"10. A discussão a seguir demonstra que embora as noções do maori selvagem e físico justificassem inicialmente a filosofia do Estado de uma educação civilizadora, um currículo racista restringiria o "selvagem nobre" ao mundo físico.

\section{A Educação Física dos maori}

A ideia de um paraíso agrícola britânico nos mares do Sul exigiu um currículo escolar para ensinar habilidades manuais, técnicas e agrícolas. Os maori, em particular, receberam uma "educação física" pú-

9-Foi comumente argumentado, de meados até o final do século dezenove, que os maori morreriam uma morte natural, vis-a-vis a sobrevivência evolutiva da filosofia mais apta. A extinção dos maori era considerada como um fenômeno infeliz, mas natural. "Tal como línguas tem substituído línguas maori, como plantas aclimatadas tem substituído plantas nativas, o homem branco substituirá os maori” (Apud. DURIE, 1998, p. 30).

10-The imperial Readers. Christchurch: Whitecombe and Tombs Ltd, 1899, p. 83. 
blica que limitou seu acesso às habilidades e qualificações necessárias para competir no mercado profissional de trabalho local. Uma retórica igualitária da educação universal para todos sustentou a provisão de educação gratuita. O desfecho de uma "educação gratuita" foi, entretanto, uma força de trabalho dócil, desenhada para assegurar os interesses do estabelecimento da classe média branca. Com a maior parte das terras pertencendo aos pākeha , treinar os maori com as habilidades de plantio só pode ser visto como o treinamento de trabalhadores para aumentar os lucros. A educação fornecida aos maori os incluiu amplamente nas áreas rurais como trabalhadores. A educação foi usada para discipliná-los, isto é, para negar, excluir, marginalizar e encerrar: "esta forma de disciplina trabalhou em um nível curricular [...] como um mecanismo para selecionar nossas garotas e crianças 'nativas' para o trabalho doméstico e manual" (SMITH, 1951, p. 68).

A discussão de John Barrington sobre a política educacional e o Te Aute College, um colégio interno predominantemente maori, fornece uma leitura perturbadora. De acordo com o diretor, John Thornton, os garotos maori atingiram um nível igual a qualquer um no país em matemática e ciências. Mas as conquistas acadêmicas dos maori alarmaram James H. Pope, o Inspetor inaugural das Escolas Nativas. Em 1866, ele sugeriu que a Te Aute deveria ensinar aos garotos maori "agricultura, jardinagem, pecuária, criação de frango e cura do bacon". Pope particularmente ressentiu os recursos do Estado "sendo desviado para o trabalho literário" (SMITH, 1951, p. 47). George Hogben, o Inspetor Geral das Escolas, assumiu o assunto junto aos representantes da Te Aute e exigiu que o Latim, a Matemática e a Álgebra fossem retirados do currículo.

De 1880 a 1940, as políticas educacionais refletiram uma "visão estreita e limitada" do potencial dos maori e de seu papel na sociedade neozelandesa (BARRINGTON, 1988, p. 45-58). Os ministros da educação consideraram a educação pākeha "muito acadêmica" para os maori. Em 1905, a educação compulsória para as crianças maori foi introduzida dois anos depois que William Bird substituiu Pope como inspetor. No ano seguinte, Bird declarou que os maori eram inerentemente inadequados para as matérias acadêmicas: "O gênio natural dos maori [vai] na direção das habilidades manuais e seu interesse natural pelo concreto parece fornecer a chave para o desenvolvimento de sua inteligência" (Apud. SIMON, 1990, p. 98). Bird acreditou que a educação não prepararia os maori para competir com os europeus no co- 
mércio e nos negócios. Em 1913, as crenças de Bird foram totalmente realizadas:

Em nenhuma escola secundária maori [...] existe qualquer tentativa ou desejo de fornecer o que é geralmente compreendido como uma educação "colegial" [...] as escolas para garotas fornecem treinamento nas matérias inglesas e diversos ramos dos deveres domésticos - culinária, costura e feitio de roupa, cuidados com a casa, puericultura e higiene; as escolas para garotos em inglês e treinamento manual - marcenaria, técnica agrícola básica e assuntos familiares e isto é tudo. (BARRINGTON, 1988, p. 53)

O reverendo Butterfield, chefe de um colégio interno maori em Gisborne, concordou, dizendo ao Partido Jovem Maori em 1910 que os maori não eram adequados para várias profissões:

Cerca de 999 de 1.000 não poderiam suportar o peso de uma educação superior. No comércio, os maori não podem esperar competir com os pākehā. Nos negócios, os maori eram esplendidos copiadores, mas não criadores. Como carpinteiros, ele lidariam com um supervisor capaz, mas não de outra forma. A agricultura é uma opção adequada para os maori [...] foi, portanto, necessário ensiná-los a "nobreza do trabalho". (BARRINGTON, 1988, p. 49)

Thomas Strong, o Diretor de Educação do final dos anos 1920 até meados dos anos 1930, ficou surpreso e desconfortável ao descobrir que os maori aprendiam "as complexidades dos cálculos numéricos" em algumas escolas. Ele alertou que educar as "raças escuras" e "encorajar os pupilos a irem para um estágio além de suas necessidades presentes ou suas possíveis necessidades futuras" seria uma "habilidade fatal" (STRONG, 1931, p. 194). Em 1941, Thomas Fletcher, o Inspetor das Escolas Nativas, identificou a fabricação de casas, construção, fabricação de móveis, culinária e criação de crianças como o currículo principal nas recém estabelecidas Escolas Secundárias dos Distritos Nativos (SIMON, 1990). Assim, os estudantes eram incapazes de ganhar as qualificações necessárias para competir no mercado de trabalho (SIMON, 1990). A filosofia de Fletcher era similar 
àquela de seus predecessores e formou o centro da política de educação maori no início do século vinte: "Levar o jovem maori a ser um bom fazendeiro e a jovem maori a ser uma boa esposa de fazendeiro" (Apud. HARKER; MACCONNOCHIE, 1985, p. 95).

A urbanização na metade do século vinte precipitou uma maior ênfase no currículo dos meninos maori em relação aos negócios para empregos nas cidades. A busca por emprego fez com que vários moços e moças maori e, consequentemente, famílias maori, deixassem seu hapu (sub-tribo). Os maori não eram mais necessários como fazendeiros e esposas de fazendeiros, eles eram necessários como carpinteiros e esposas de carpinteiros (RAMSAY, 1972, p. 68-80). A próxima seção examina a inovação da Educação Física pública como a primeira área de estudo para incluir a cultura maori. Entretanto, ela questiona se isto beneficiou os maori, ou perpetuou ainda mais seu estereótipo como um povo físico.

\section{A Educação Física pública e os maori}

Deve ser dito, em primeiro lugar e de forma mais notável, que a adesão do Estado ocidental ao modelo clássico de educação grega de "matérias, disciplinas e planos de ensino como conjuntos ou domínios de significado" (YOUNG, 1971, p. 27) corroeu a natureza holística do mätauranga Māori (conhecimento e sistemas de aprendizado maori). O sistema imperial de fragmentação denegriu a compreensão maori do mundo (SMITH, 1999). A quebra da vida maori em seções, subseções e categorias que se alinharam com as percepções europeias do mundo violaram o conhecimento maori. Como uma área de estudo distinta, a Educação Física, por exemplo, contrastou uma visão holística maori da saúde e da atividade física (DURIE, 1994).

Inicialmente, a Educação Física na Nova Zelândia (para as classes trabalhadoras, pelo menos) teve base militar. Em 1901, a Lei de Escolas Públicas e Nativas determinou que os exercícios físicos para meninos e meninas, com oito anos de idade ou mais, seriam obrigatórios. Em parte, como reação à noção de que os neozelandeses deveriam proteger sua costa, o novo currículo de Educação Física ignorou ironicamente o sucesso engenhoso e tático dos maori nas batalhas com as tropas britânicas (BELICH, 1988). Mesmo as Escolas Nativas não reconheceram os exercícios militares e o armamento maori. Demonstrando a extensão com que a Educação Física estava vinculada a uma 
visão de mundo imperial, os educadores físicos ${ }^{11}$ desta época rejeitaram tudo que era maori; pois defendiam que eles não poderiam oferecer nada ao mundo moderno, especialmente se estas ofertas contradissessem as noções britânicas de superioridade.

Em 1909, o plano de ensino do Conselho Inglês de Educação para os exercícios físicos forneceu o primeiro "espaço claramente definido" oficialmente no currículo para a Educação Física. Sua introdução marcou a consciência crescente de que o exercício poderia facilitar a aptidão mental e sinalizou uma mudança para longe do exercício mili$\operatorname{tar}$ (ROYDHOSE, 1947, p. 155-157). Mas a referência à saúde holística ignorou completamente a tikanga Māori. Entre os maori, as bases de saúde da complexa ideia de Mauri (princípio de vida) incluem hauora (literalmente o "sopro de vida", mas comumente referido como saúde holística), que, por sua vez, é regulada por whenua (relação com a terra), wairua (o elemento espiritual), hinengaro (o elemento mental), whānau (o elemento familiar) e tinana (o elemento físico). Tal filosofia era condizente com a suposição básica que sustentou a política e a prática da Educação Física na Nova Zelândia, "Um corpo saudável cria uma mente saudável" (BURROWS, 2000, p. 206), e seria, portanto, integrada ao currículo.

Entretanto, em 1930, a percepção da cultura maori como completamente irrelevante ao mundo "moderno" sofreu modificações. Nos anos entre guerras, a sociedade pākeh $\bar{a}$ reconheceu cada vez mais os poderes adaptativos dos maori, bem como seu orgulho como povo. Até certo ponto, o renascimento cultural dos maori nos anos 1930, liderado por Sir Apirana $\mathrm{Ngata}^{12}$, foi reconhecido pela sociedade atual. Além disso, os maori começaram a ser aceitos como cidadãos. Os periódicos escolares descreviam cada vez mais uma sociedade igualitária na qual os vizinhos maori haviam sido assimilados: "Estamos acostu-

11- NR: Neste caso, o termo inglês usado foi "physical educanionalists", o que realmente coincide com a noção de educador físico, a qual se contrapõe, ao menos em certo sentido, à noção atual de "professor de Educação Física", principalmente porque no contexto ao qual se remete o autor, parece-nos mais adequado a ideia de um instrutor de Educação Física.

12-Um dos mais efetivos e significativos líderes maori na primeira metade do século vinte, que ganhou ganhando aplausos e posições de poder nos mundos maori e pakeha.

Pensar a Prática, Goiânia, v. 15, n. 1, p. 1-271, jan./mar. 2012 
mados a ver os maori sentados à mesa com europeus, falando com eles nas ruas e competindo de forma igualitária em diversos esportes e ocupações. O bom maori está no mesmo nível que o bom pākehā e o mal pākeha afunda tanto quanto o mal maori" (NEW ZEALAND EDUCATION DEPARTMENT, 1909, p. 115-116). Observe que a palavra "diversos" se refere a certas áreas da vida, mas não todas!

Junto com a noção do "vizinho" maori estava um senso de desenvolvimento do vínculo cultural. Locais apropriados onde a tikanga Māori poderia ser integrada nos ambientes mainstream foram selecionados. Consequentemente, a educação pública "teve necessariamente" que se aliar ao renascimento cultural de Ngata (BALL, 1940, p. 300). A introdução da tikanga Māori nas escolas nativas foi limitada às escolas primárias e incluía somente os aspectos não ameaçadores, tais como "música, ofícios, arte, história e dança" (NEW ZEALAND EDUCATION DEPARTMENT, 1941, p. 190). Isto sinalizou o uso inicial da cultura maori pelo sistema público de educação como instrumentos de adorno para criar uma atmosfera de cultura artificial, enquanto se ignorava a tikanga Māori de qualquer substância, tal como o idioma.

Uma grande parte do conteúdo maori ensinado nas Escolas Nativas era considerada Educação Física. A cultura maori era percebida como uma cultura do "fazer" e, consequentemente, a Educação Física era considerada uma área apropriada para sua integração:

Cada aprendiz equilibra o exercício mental com o físico e compensa ambos com um certo período de relaxamento. As aulas de educação física são realizadas pela manhã. $\mathrm{O}$ intervalo de jogos é devotado a exercícios de agilidade e jogos, incluindo jogos maori tais como homai [jogos de mão], jogos com varas, peão e jogos com cordas [...] No fim da tarde, quando as crianças estão ficando mentalmente cansadas, temos mais um período de quinze minutos para jardinagem ou pois [uma bola conectada em um cordão para dar flexibilidade e destreza aos pulsos e mãos], músicas de ação [...] para compensar a fadiga mental e liberar a energia física acumulada [...] Em termos da teoria educacional moderna, o trabalho manual nativo se encaixa no programa do "fazer", o aspecto atraente e importante de qualquer escola [...] Como um "enfeite dourado" para as atividades ativas está o poi, haka e as músicas de ação. Todos estes exibem características 
rítmicas notáveis. (NEW ZEALAND EDUCATION DEPARTMENT, 1941, p. 195)

Ao mesmo tempo, a educação atual também começou a se sentir culturalmente obrigada a introduzir a tikanga Māori em seu currículo. Como as Escolas Nativas, as escolas tradicionais consideraram a Educação Física como sendo o local apropriado para a sua inclusão. Phillip Smithells é geralmente considerado como o pioneiro para a introdução da tikanga Māori na Educação Física pública. Ele recebeu os créditos como o primeiro pedagogo a fazer "aberturas aos professores e estudantes maori desde o início da educação formal" (BURROWS, 1960, p. 216). A discussão a seguir examina os efeitos que as ações de Smithells tiveram sobre os maori.

O Departamento de Educação empregou Smithells (um membro da classe alta inglesa educado em Cambridge) para implementar o currículo educacional inglês de Educação Física de 1933 nas escolas da Nova Zelândia. Smithells "se empenhou para promover uma versão neozelandesa única dos ditados ingleses" (BURROWS, 1960, p. 216). Uma década depois, Smithells tornou-se Reitor da Escola de Educação Física da Universidade de Otago, em Dunedin. Consequentemente, dos anos 1930 até sua aposentadoria nos anos 1970, Smithells exerceu imensa influência na direção da Educação Física na Nova Zelândia.

Smithells começou sua busca pelo desenvolvimento de um programa de Educação Física único para a Nova Zelândia, recrutando homens e mulheres selecionados para treinar os professores no novo sistema (STOHART, 1996, p. 16). Em 1947, entre 70 e 80 organizadores treinados promoveram a visão de Smithells sobre a Educação Física, que incluía práticas maori. Em uma entrevista nos anos 1970, Smithells resumiu seu conceito:

Minha idéia desde o começo era tentar e descobrir o que se adequaria à Nova Zelândia, tirando idéias de diversos países e também de qualquer coisa indígena que tivesse valor. Em 1940, percebi que diversas atividades físicas maori eram excelentes por si só e peculiares para a Nova Zelândia [...] [de 1941] em diante [homens e mulheres] foram treinados em atividades maori como uma parte essencial da Educação física. (Apud. ROSS, 1998, p. 3) 
Smithells viu valor educacional nos jogos "rítmicos maori" e "buscou recuperá-los para o uso em escolas maori e pakeha" (SMITH, 1951, p. 318). Ele instruiu a equipe a "coletar atividades ou fotografálas" conforme eles viajavam pelo país treinando professores. Mais tarde ele afirmou que sua equipe "resgatou" "diversos jogos e atividades" (STOHART, 1996, p. 18).

O discurso dominante que circundava a relação de Smithells com os maori celebra Smithells como um visionário. De acordo com Bob Stothart (1992, p. 4), Smithells iniciou uma aliança de 50 anos com o movimento maori:

O grande e gentil Philip Smithells reconheceu intuitivamente a importância do movimento maori durante os anos 40 e encorajou os consultores [...] a fotografar e reunir informações. As publicações de educação física da Nova Zelândia capturaram consistentemente uma dimensão maori, resultando diretamente do interesse inicial de Smithells.

Da mesma forma, Mike Boyes (1998, p. 1), um membro atual da equipe da Escola de Educação Física, descreve uma relação durável entre a educação física e a tikanga Māori inaugurada por Smithells:

Por quase 60 anos, os professores de educação física tinham um grande interesse nas atividades físicas dos maori. Philip Smithells nos anos 40 promoveu ativamente a coleta e valorização destas atividades e por décadas as crianças em idade escolar da Nova Zelândia aproveitaram e foram desafiadas pelo aprendizado através deste contexto de movimento.

De acordo com Annette Golding, Smithells obteve reconhecimento de diversos educadores físicos de "diversos jogos e danças do povo maori. Desde então, professores, especialistas e estudantes têm tido acesso a um repertório considerável de jogos de mão, cordão e vara, danças poi, músicas de ação e hakas". Maharaia Winiata, entre outros maori, "congratulou publicamente [Smithells] em diversos marae [local de reunião da comunidade] pelo trabalho que ele realizou em unir e preservar" (STOHART, 1996, p. 4).

A profissão de Educação Física na Nova Zelândia, por sua vez, se 
orgulha de ser "amiga dos nativos" e quanto as descobertas e resgates das atividades físicas dos maori:

Este jogo [titi tūrea] possui uma história interessante da qual nossa profissão pode se orgulhar bastante. Até 1945, ele não era um jogo de varas Maori muito conhecido. Ele foi descoberto em uma pequena escola Maori que tinha somente um professor, Kokako. June White que era o organizador assistente em Gisborne naquela época e que era particularmente interessado em jogos de varas Maori o reconheceu como sendo essencialmente diferente dos jogos com varas Maori que conhecíamos [...] June o ensinou para a Equipe de Educação Física do Departamento de Educação em um Curso de Atualização em Wanganui, no início de 1947. Desde então ele se espalhou por todo o território. Este é somente um exemplo de vários indicando como os educadores físicos neste país mantiveram viva uma parte da cultura Maori que poderia ter morrido. (NEW ZEALAND EDUCATION SOCIETY, 1956, p. 28)

É comumente aceito pelos educadores físicos da Nova Zelândia, portanto, que Smithells era "pró-maori”. Enquanto isto parece correto, especialmente no contexto da educação pública da Nova Zelândia nos anos 1940, ainda existem dúvidas em relação aos efeitos das ações de Smithells sobre os maori, particularmente a perpetuação dos seus estereótipo e má representação.

Smithells quase sempre descreve as atividades físicas maori em termos de sua reprodução para concretizar os resultados ocidentais. Lisette Burrows observa dois discursos dominantes circundando o valor da Educação Física nos anos 1940. O primeiro era centrado na criança, com abordagem de solução do problema, enfatizando "modos mais livres, menos ditatoriais de ensinar e a promoção da criatividade humana" (BURROWS, 1960, p. 187). Isto é claramente evidente no trabalho de Smithells:

Os Maori podem dar aos Pakehas a mesma quantidade de movimentos ginásticos saudáveis úteis quanto os Pakehas podem dar aos Maori. Por esta razão [...] o tipo mais simples de atividade rítmica Maori deve se tornar uma parte básica da educação física $[. .$.$] isto dará um novo tipo de divertimento, prazer e des-$ 
canso para todos que experimentarem [...] esses jogos são divertidos de se aprender ${ }^{13}$.

Um segundo discurso enfatizou a cientificismo progressivo da Educação Física e a "categorização, medição e controle do movimento do corpo" (BURROWS, 1960, p. 188). Em um artigo intitulado "Ritmo maori", Smithells confina a tikanga Māori dentro dos conceitos científicos ocidentais: "O ato de dobrar os joelhos na forma Maori oferece uma melhor posição pélvica do que a posição formal usual com as pernas esticadas [...] Uma análise anatômica detalhada de todas as posições usadas nas atividades Maori mostrou que as posições usadas são corretivas e contribuem para o desenvolvimento" (SMITHELLS, 1941).

$\mathrm{O}$ ponto desta discussão não é lamentar o reconhecimento de Smithells em relação à cultura maori, nem sugerir que ele deveria ter compreendido a tikanga Māori. Na verdade, Smithells se afastou dos parâmetros de seus contemporâneos e da sociedade neozelandesa. Ele somente apreciou as funções rudimentares das práticas corporais maori. Elas foram definidas dentro dos conceitos ocidentais e, assim, tendo seus fundamentos culturais ignorados. Da perspectiva maori, as ações de Smithells foram tão supressivas quanto o encobrimento da cultura maori. Não é minha intenção tornar Smithells um vilão, ao invés disso, meu objetivo é dar voz à realidade dos maori: as ações dos pakehas "amigos dos maori" também tiveram consequências. Anne Salmond (1983, p. 318) afirma que a "ausência de qualquer tentativa séria de descobrir como o material poderia ser ordenado da forma Maori [...] responde à demanda ocidental por descrições ordenadas das 'áreas' de vida, mas também encurta as formas de compreender o passado [...] [que] são organizadas ao longo de linhas bastante diferentes".

A classificação de Smithells em relação às práticas culturais maori como o "Ritmo maori" demonstra aos maori, pelo menos, que ele não compreendia como esse povo concebia seu mundo e desta forma, intencionalmente ou não, ele fragmentou o mundo maori para torná-lo semelhante tanto quanto possível ao mundo europeu e ao seu entendimento errôneo da cultura maori: "As rotinas de Taiaha [arma de curta

13-SMITHELLS, P. Philip Smithells' papers. Archiveal material Nunedin: Hocken Library, p. 205.

Pensar a Prática, Goiânia, v. 15, n. 1, p. 1-271, jan./mar. 2012 
distância] - algumas delas extremamente rítmicas - são acompanhadas pelo que parecem ser maldições contra o inimigo, gesticulações, caretas e a sempre presente protrusão de línguas que os Maori amam usar e que aparecem repetidas vezes em suas fascinantes esculturas" (SMITHELLS, 1941, p. 7). Aqui está o problema da classificação dos pakehas para a cultura maori. Enquanto poi, taiaha e mau rakau (atividades com vara) podem ter parecido como sendo passatempos rítmicos para Smithells, os maori os concebem diferentemente. Basta contrastar o entendimento de Smithells com aquele do proeminente analista kapa haka, Timoti Kāretu: "a língua é a avenida pela qual os pensamentos da mente são conduzidos à audiência. É, portanto, correto que a língua deva ser honrada, como é feito nas esculturas dos ancestrais do sexo masculino. Como a pūkana [dilatação dos olhos], a whètero [protrusão da língua] é usada para enfatizar certas palavras, frases ou referências" (KARETU, 1998, p. 29-31).

O pesquisador maori, Peter "Te Rangihiroa" Buck, nos alerta sobre o fato de que nenhuma prática cultural pode sobreviver em um vácuo descontextualizado. O que Smithells divulgou no currículo principal e que deveria ser tendência na Educação Física e na educação em geral não era a tikanga Māori - eram meramente algumas palavras e ações maori:

Os antigos jogos Maori praticamente desapareceram e foram substituídos pelos jogos aprendidos com as crianças Pākeha $[. .$. O jogo Tops sobreviveu por que é usado pelas crianças européias, mas os antigos cânticos que o acompanhava foram esquecidos. Os adultos não se interessam mais por ele uma vez que o uso social ao qual ele estava conectado desapareceu. Pipas, se ainda existem, possuem a forma de construção do Pākeha e os padres que as usavam para adivinhações estão extintos como uma classe. (BUCK, 1949, p. 250)

Assim, enquanto Smithells sonhava com uma Educação Física temperada com movimentos indígenas, os maori não viam propósito em desempenhar atividades que não tinham os outros elementos essenciais, que eram combinadas para formar uma filosofia holística. $\mathrm{O}$ aspecto menos importante do poi, mau taiaha ou jogos com varas era o aspecto físico (HOKOWHITU, 2002). Encantamentos e histórias 
que rodeavam estas atividades permitiram a regeneração da whakapapa (genealogia) e da tikanga.

As visões descontextualizadas de Smithells da tikanga Māori não propagaram a cultura maori dentro da sociedade dominante, nem ofereceram uma melhor compreensão dessa cultura aos pedagogos, muito menos ao público leigo. A relutância de Moana Nepia em participar de algumas atividades durante sua Educação Física nos anos 1950, uma vez que elas eram inapropriadas culturalmente, atesta essa incompreensão: "Um dos jogos que nos fazia realmente whakanna [diminuídos] era o túnel de bola e canguru (leapfrog). Eu não podia fazer aquilo. Os professores nos obrigavam a participar e não tínhamos como não fazer e explicar o motivo, uma vez que poderíamos ser acusados de querer escapar da Educação Física" (Apud. METGE, 1986, p. 49-50). De forma similar, Rewiti Webster descobriu que seus educadores eram menos do que simpáticos em relação às práticas corporais maori:

Logo se tornou bastante claro para mim que as coisas Maori não eram coisas das quais eu deveria me orgulhar. Instruíamnos a não falar Maori no parquinho, nós éramos repreendidos [...] Eu fazia tops e levava meu flax whip (chicote) para a escola. Eu achei que apresentaria este jogo para eles. A professora disse, “Que tipo de jogo Maori é este?". (Apud. METGE, 1986, p. 49-50)

A aceitação da tikanga Māori dentro do currículo de Educação Física pelo Departamento de Educação na época de Smithells era crescente e acompanhada por uma empatia igualmente crescente por certos aspectos da cultura maori (isto é, práticas dentro do reino físico que não fossem acadêmicas ou ameaçadoras). Um grau similar de obrigação para incluir o conteúdo maori no currículo pode ser observado na Escola Nativa (SIMON, 1998). A inclusão da cultura maori na Educação Física era uma solução ideal para o compromisso cultural, uma vez que essa disciplina era considerada não acadêmica; ao mesmo tempo em que mantinha também o estereótipo maori como um povo com habilidades físicas. A próxima seção explora como o esporte, assim como a Educação Física, se tornou uma arena aceitável para a realização maori devido a sua localização no reino físico. 


\section{A naturalização do atleta maori}

Os maori conquistaram mais nos esportes do que em qualquer outra área na sociedade da Nova Zelândia. O esporte foi a única atividade principal na qual onde os maori puderam ter sucesso e competir com os pākehās em um "campo competitivo igualitário", podendo, desta forma, ganhar mana (respeito/ estima) no mundo pākehā. Inicialmente, os líderes maori viam o esporte como uma forma de embelezar sua própria cultura enquanto se integravam à sociedade dominante. No início do século vinte, com sua cultura em vias de extinção e sujeita ao racismo explícito em quase todos os circuitos da sociedade, o esporte ofereceu aos maori um tipo de salvação. Além disso, considerando a histeria nacional pelo rúgbi durante o século vinte, bem como o status do jogo, não é de se surpreender que os maori tenham colocado o mana em serem "excelentes jogadores". Só é preciso ver os obituários na Mana Magazine ${ }^{14}$ para ver como os maori honram as façanhas esportivas.

Os maori, assim como diversos grupos colonizados, tiveram acesso condicional ao mundo do colonizador. Por exemplo, os homens maori, como guerreiros, "se mostravam bons nas coisas em que os homens Pākehā [também] se orgulhavam. Os homens Maori eram bons na guerra e eram muito bons em jogar rúgbi, então eles assumiram um status especial de serem homens Kiwi ${ }^{15}$, com um leve toque exótico" (Apud. SCHIKk; DOLAN, 1999, p. 56). A guerra e o rúgbi eram dois dos poucos campos em que os homens maori eram capazes de adentrar o domínio pākehā em um "nível competitivo" (MACLEAN, 1999). Os maori ganharam acesso a estas arenas por que eram "muito bons" mas, sobretudo porque as representações dos atletas ou guerreiros maori não entravam em conflito com os seu estereótipo como um povo físico e selvagem: “Os Maori, por sua natureza selvagem, deveriam lutar -

14-Uma revista mensal dedicada aos assuntos, histórias e eventos maori.

15- NE: Kiwi é uma espécie de ave nativa da Nova Zelândia, que se tornou símbolo do país, passível de ser utilizada, inclusive, como adjetivo para coisas diversas, tal como culinária kiwi, cultura kiwi etc. Mais que isso, pessoas da Nova Zelândia definem a si mesmas como Kiwis. Particularmente, empregado na definição de um tipo de masculinidade, "homem Kiwi" diz respeito a um arquétipo de força, vigor etc.

Pensar a Prática, Goiânia, v. 15, n. 1, p. 1-271, jan./mar. 2012 
na guerra ou em seu substituto durante os tempos de paz, o rúgbi. Nenhum exige intelecto" (MACLEAN, 1999, p. 21). O rúgbi e a guerra exigem bravura física e podem ser brutalmente violentos, especialmente onde os maori são tipicamente encontrados: no scrum $^{16}$ ou nas trincheiras dos campos de batalhas (HOKOWHITU, 2003).

A transformação do maori em atleta começou como um comentário sobre o "nobre selvagem". Uma minoria significativa de comentaristas, tais como Rousseau, acreditava que o Outro selvagem era moralmente superior uma vez que vivia mais perto da natureza (MILES, 1989). Entretanto, a noção de Rousseau sobre o nobre selvagem era uma crítica ao estado da sociedade civilizada, em vez de uma sugestão de que a sociedade moderna deveria voltar às formas selvagens do Outro. Correspondentemente, muitos dos primeiros viajantes romantizaram os selvagens como parte de um "mundo natural" cheio de "inocência e pureza" em oposição à "corrupção e decadência" do mundo desenvolvido (SMITH, 1999, p. 49). Ao romantizar o nobre selvagem em casos de extraordinário perfil atlético, as representações ocidentais dos maori ofereceram uma importância humanística de uma vida lindamente ingênua, simples e mística antes da vida fundamentada e imbuída pela revolução científica. Um dos primeiros viajantes que foi para a Nova Zelândia, por exemplo, relata uma animada história do "maori bronzeado" competindo em uma batalha primordial já há muito tempo perdida contra a natureza:

A canoa agora estava deslizando rapidamente pela correnteza [...] seu experiente timoneiro, tão rígido como se fundido em bronze [...] A impressão mais duradoura em minha mente neste incidente foi o equilíbrio e habilidade de Te Rangi Tuataka Takere, o nascido Rangatira [chefe], conforme ele sentava como uma estátua, o remo firmemente agarrado, sua delicada figura muscular e características tatuagens precisas, reproduzindo [...] uma grande imagem do puro reino Maori como ele havia sido durante séculos. Alas! Que nunca mais testemunharíamos uma cena como esta novamente. (SKINNER, 1923, p. 35-37)

O entendimento dos esportes europeus pelos maori teve duas fun-

16-NE: O scrum é uma situação no rúgbi, na qual jogadores das equipes formam duas linhas opostas entre si para disputar a posse de bola.

Pensar a Prática, Goiânia, v. 15, n. 1, p. 1-271, jan./mar. 2012 
ções para o grupo dominante. Primeiramente, o esporte era sem dúvida uma forma de controle social: "o rúgbi e o cricket, famosamente descritos como 'o presente britânico para o mundo', marcaram os contornos do Império. $\mathrm{O}$ esporte começou a ser visto como uma preparação essencial para o caráter e para o serviço no Império" (BEYNON, 2002 , p. 42). Os esportistas maori eram os maiores troféus da colonização; o bruto disciplinado - sua agressão e selvageria confinados em uma arena esportiva. $\mathrm{Na}$ verdade, a Imprensa britânica retratou o primeiro time nacional de rúgbi da Nova Zelândia em tour pela Grã-Bretanha, o Time Nativo de 1888-89, como uma exibição circense, exibindo selvagens domados dos mares do Sul (RYAN, 1993). Os neozelandeses sentiram que a atuação do time de Rugby Nativo de 18881889 poderia "construir ou destruir a ampla reputação da jovem colônia", e foi com satisfação que os neozelandeses ouviram sobre seu próprio sucesso de colonização. O Daily Telegraph (de Londres) relatou: "Os Maori certamente progrediram desde que o Capitão James Cook [...] encontrou os ancestrais delicadamente pintados e caprichosamente tatuados, comendo uns aos outros em um arbusto" (RYAN, 1993, p. 44-45). O The Times (também de Londres) afirmou: "é um tributo à capacidade dos nossos colonizadores. A raça colonizadora que pode imbuir os habitantes aborígines dos países colonizados com um amor por seus jogos nacionais [...] Onde quer que o homem inglês vá, ele leva o bastão e as traves" (RYAN, 1993, p. 50).

Em segundo lugar, reconciliaram os maori com o público pākehā. A transformação dos maori em atletas ajudou o projeto colonial, fornecendo uma ponte para a cultura dominante reconhecer certo bem em seus irmãos mais escuros. Os maori foram assimilados na sociedade através das atividades físicas, fosse através da bravura de guerra, trabalho físico, Educação Física, esporte ou através de sua aptidão com a atividade física. Os maori foram valorizados pelo público uma vez que, nas palavras de Smithells (1941), eles tinham "ritmo":

Por incontáveis anos de experiência, tentativa e erro, estas atividades rítmicas evoluíram com o objetivo de atribuir rapidez das mãos e olhos, ritmo, antecipação e o fortalecimento de certos grupos musculares. Além dos efeitos físicos diretos de grande controle motor, existe a alegria e divertimento que provém de tal controle do corpo se movendo de forma rítmica, seja nas 
varreduras selvagens da taiaha, na batida do staccato do homai [jogo de mão] ou no ritmo suave e contínuo dos jogos de varas.

Smithells apresentou os maori como mestres do movimento: "O $P \bar{a} k e h \bar{a}$ pode ter ensinado aos Maori diversos jogos, mas ele pouco o ensinou sobre movimento [...] podemos tentar aprender dos Maori alguns dos fatores básicos de movimento, ritmo, relaxamento e coordenação, assuntos os quais ele muito sabe" ${ }^{17}$. De forma controversa, ele decretou o desastrado pākeha como a antítese do maori: "O Pākeha, que é geralmente mais lento na antecipação e, devido à tensão muscular e outros fatores, é muito menos rítmico do que seu conterrâneo Maori" (SMITHELLS, 1941). Enquanto aparentemente complementares, a partir da perspectiva maori, tais noções meramente reforçaram os estereótipos predominantes de que os maori não possuíam a psicologia de uma pessoa branca, que, por sua vez, dava a ela uma "naturalidade". Tal construção está implicitamente relacionada à reivindicação cartesiana de que a razão civilizada tinha que ser imparcial e assim separada das paixões do corpo, enquanto o "fluxo" inconsciente do atleta maori era sintomático da derivação de uma cultura mais primitiva.

E em terceiro lugar, representações dos estereótipos da selvageria, agressividade e fisicalidade do atleta Maori perpetuaram-se. O discurso que acompanha o sucesso dos maori nos esportes estava bastante relacionado ao darwinismo social que validou a colonização com base nos ideais humanitários. De acordo com esse discurso, os esportistas maori prosperaram porque eles tiveram que evoluir completamente para fora do reino físico do mundo animal, para dentro dos escalões da Europa iluminada. Por exemplo, Gordon Slatter descreve o principal "atacante" [flanker] maori e dos All Black ${ }^{18}$, Waka Nathan, como um predador escorregadio semelhante a um animal que tinha um "grande instinto" e uma "grande habilidade natural" encorpada em uma "esplêndida psique", "escuros músculos encrespados" e "ágil velocidade", valendo-lhe o apelido de "Pantera Negra". Slatter continua a justificar o pseudônimo citando a Enciclopédia Britânica: "O leopardo

17-SMITHELLS, P. Philip Smithells' papers. Archival material. Nunedin: Hocken Library, p. 205.

18-NE: Maneira pela qual se conhece a seleção neozelandesa de rúgbi. 
ou pantera é rápido e gracioso, obtendo sua presa saltando sobre ela a partir de uma armadilha ou uma perseguição secreta. Nunca um apelido [de Waka Nathan], Pantera Negra, lhe serviu tão bem do que quando ele surgiu repentinamente para capturar Ranfurly Shield" (SLATTER, 1970, p. 83-84) ${ }^{19}$. Tal construção, enquanto abertamente positiva, está implicitamente relacionada ao cruel discurso animal do século XIX.

Em cumplicidade com a ideia de que o esportista maori possui atributos de origem genética está a advertência de que a habilidade física natural é paralela a uma falta inerente de propósitos mentais. Este conceito foi desenvolvido a partir da noção de que a inteligência e a força moral do pākeha sozinhos resultaram no desenvolvimento econômico e cultural da Nova Zelândia. Tal discurso encontra-se ainda evidente neste comentário do jornalista esportivo mais celebrado da Nova Zelândia, Murray Deaker: "Acho fantástico que tenhamos estes maravilhosos grupos atléticos de pessoas que podem nos ajudar a desenvolver nosso esporte [...] mas eu também quero que o fazendeiro branco, que é duro e forte, faça parte do All Black, ao meu lado [...] [O tipo de jogador que está] lá por 80 minutos de forma intransigentemente implacável" (Apud. MATHESON, 2001). Ex-jogador do All Black, Grant Fox sugere que os "jogadores polinésios eram naturalmente superiores a nós em talento, mas vários deles não estão mais lá por que não tinham a disciplina para o condicionamento físico. Eles não tinham o tipo certo de atitude mental. Eles simplesmente apareciam e jogavam" (HYDE, 1993). Enquanto o técnico de rúgbi do time de Auckland, Dale Atken, sugere que "os garotos polinésios são atleticamente explosivos e isto está igualado por sua concentração. Quando você faz a comparação com os garotos brancos, bem, eles são trabalhadores para 80 minutos. Eles são os trabalhadores" (Apud. MATHESON, 2001). Uma vez que a educação pública deu aos maori somente as habilidades físicas necessárias para fornecer trabalho nas terras do $p \bar{a} k e h \bar{a}$, eles têm crédito somente por terem um aspecto atlético natural; uma vez que, de acordo com a análise acima, foram a inteligência e a integridade do Pākehā que tornaram a Nova Zelândia o país que é hoje, da mesma forma que é a determinação obstinada do pākeha que

19-Referencia ao famoso try de Nathan, marcado na vitória do Ranfurly Shield em Auckland contra o Canterburry, em 1960. O Ranfurly Shield é o mais cobiçado troféu esportivo da Nova Zelândia. 
irá ganhar os jogos para os All Blacks no futuro. Embora o esportista maori atue como um exemplo de um indivíduo dentro de um estado igualitário que triunfou em relação às adversidades, a representação também pode ser usada para sugerir implicitamente que o maori não possui ética no trabalho, é preguiçoso e instável.

\section{Conclusão}

Constantes representações com o passar do tempo causam o que Foucault chama de "regime exibicionista da verdade". Como Edward Said (1978, p. 94) argumenta, o colonialismo "pode criar não somente conhecimento, mas também a realidade que ele parece descrever" (p. 94). Em geral, a genealogia de representar os maori como pessoas físicas criou uma cultura na Nova Zelândia que direciona esse povo para o reino físico; o atleta maori e o trabalhador manual representam "aquela parte do passado que ainda é operante no presente" (NIRANJANA, 1992, p. 37). Os estereótipos dos maori não são perigosos por serem falsas representações de uma determinada realidade, eles são perigosos por serem uma "forma presa, fixa de representação que, ao negar a diferença, constitui um problema" (BHABHA, 1983, p. 27).

O estereótipo dos maori como pessoas físicas continua sem qualquer redução. Recentemente, Farah Palmer descobriu que diversos professores de escolas secundárias viam as conquistas maori puramente dentro do reino físico ou dos esportes. Um professor disse "existe um certo estereótipo para os Maori e Pakehas que precisamos encarar [...] os Maori são bons em Educação Física [...] [Precisamos] garantir que a estrutura dos cursos seja moldada de acordo com esses interesses, tais como esportes, de forma que haja uma aplicação prática com a qual eles possam se relacionar" (grifo do autor) (Apud. PALMER, 2000 , p. 275). Outra professora baseou sua opinião sobre os maori no sucesso nos esportes: "Gosto dos alunos Maori por que eles são bons nos esportes e são entusiastas em relação a isto" (PALMER, 2000, p. 276). Em geral, os professores acreditaram que os estudantes maori possuíam atributos naturais para serem "bons atletas", mas tinham "expectativas muito baixas em relação às [suas] capacidades acadêmicas" (PALMER, 2000, p. 309-310). O esporte maori se tornou um representante da construção do trabalhador físico estilizado que limitou seus pais, avós e bisavós a criados nos negócios dos pākehā.

Vestígios históricos da selvageria e da fisicalidade dos maori foram

Pensar a Prática, Goiânia, v. 15, n. 1, p. 1-271, jan./mar. 2012

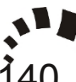


promulgados através da educação pública, Educação Física e esportes. As três arenas culminaram junto com as outras instituições, tais como a mídia, para formar uma construção poderosa do maori como um ser físico. Enquanto a educação inicialmente justificou a civilização dos maori selvagens através da representação dos mesmos como pessoas fisicamente bárbaras, a fisicalidade maori foi usada mais tarde para integrá-los à sociedade $p \bar{a} k e h \bar{a}$ através da Educação Física e dos esportes. Não há qualquer mal entendido de que a Educação Física tenha sido a única matéria na educação pública por mais de três décadas (anos 1940 aos anos 1970) a apresentar conteúdo maori: estar disposta no reino físico / não acadêmico fez dela, por seu desenho, a única matéria para a inclusão do tikanga Mãori. Similarmente, o esporte permaneceu, durante cerca de um século, como a única instituição (além do entretenimento) em que o sucesso maori ganhou representação consistente. A naturalização dos maori como pessoas físicas se tornou um regime exibicionista de verdade, no qual o sucesso dos maori no campo dos esportes, nas fazendas ou dentro da Educação Física continua a justificar a sua representação como um povo físico.

Physical beings: stereotypes, sport and physical education of Maori in New Zealand

\begin{abstract}
This essay examines how sport, State education and physical education have contributed to the suppression of the indigenous New Zealand Maori by promulgating their stereotype as a physical and unintelligent people. It begins by providing an historical genealogy of the savage physical Maori stereotype. Next, this stereotype is shown to have justified a racist education system that channelled Maori into manual, as opposed to academic, areas. Later, Maori culture and Maori successes were afforded inclusion only within non-threatening domains such as physical education and sport. The ramifications of physical education becoming the first subject area to offer overtures to Maori, are examined. Lastly, I suggest that the naturalization of Maori as sportspeople contributed to the colonization process by assimilating Maori in an area that highlighted their supposed inherent physicality.
\end{abstract}

Keywords: Sport. New Zealand. Indigenous. History.

Seres físicos: estereotipos, deporte y la educación física dos Maori de Nueva Zelandia

\title{
Resumen
}

Este artículo examina cómo el deporte, la educación pública y la educación física han contribuido a la supresión de los indígenas Maorí de Nueva Zelanda mediante 
el fomento de sus estereotipos como seres físicos y no inteligentes. El artículo comienza haciendo una genealogía histórica del estereotipo físico y salvaje Maorí. Entonces, este estereotipo se usa para justificar un sistema educativo racista, que canaliza los Maorí para las actividades manuales, a diferencia de las áreas académicas. Más tarde, en la cultura Maorí se ofrecen sólo áreas que poco peligrosas para tales estereotipos, tales como la educación física y el deporte. Las ramificaciones de la educación física se convirtió en el primero de los conocimientos a ofrecer puestos a los Maorí. Por último, sugiero que la naturalización de los atletas Maorí contribuye al proceso de su asimilación en una zona que destaca su físico supuestamente inherente.

Palabras clave: Deporte. Nueva Zelandia. Indigenas. Historia.

\section{Referências}

BALL, D. G. Maori education. In: SUTHERLAND, I. G. (ed.). The Maori people today: a general survey. Wellington: The New Zealand Institute of International Affairs and the New Zealand Council for Educational Research, 1940.

BARRINGTON, J. Learning the "dignity of labour": secondary education policy for Maoris. New Zealand Journal of Education Studies, vol. 23, issue $1,1988$.

BARRINGTON, J.; BEAGLEhole, T. Maori Schools in a Changing Society: an historical review. Wellington: New Zealand Council for Educational Research, 1974.

BEDERMAN, G. Manlines and civilization: a cultural history of gender and race in United States, 1880-1917. Chicago: University of Chicago Press, 1995.

BELICH, J. The New Zealand Wars and the Victorian Interpretation of Racial Conflict. Auckland: Penguin, 1988.

BEST, E. Games and pastimes of the Maori. 2nd. Edition. Wellington: A. R. Shearer, Government Printer, 1976.

. Games and pastimes of the Maori. Wellington: The Board of Maori Ethnological Research for the Dominion Museum, 1925.

BEYNON, J. Mascilinities and culture. London: Open University Press, 2002. 
BHABHA, K. K. The other question. Screen, vol. 24, n. 6, 1983.

BOYES, M. Editorial. Journal of Physical Education, New Zealand, vol. 31, issue 1, 1998, p. 1.

BUCK, P. The coming of the Maori. Wellington: Maori Purposes Fund Board / Whitcombe and Tombs, 1949.

BURROWS, L. Mapping discourses of physical education in New Zealand: 1877-1960. Ph.D. thesis. University of Otago, 2000.

CORNEWLL, J. A. School geography. London: John Murray, 1881.

CORNWALL, A.; LINDISFARNE, N. Dislocating Masculinity: Gender, Power and Anthropology. In: CORNWALL, A.; LINDISFARNE, N. (eds.). Dislocating Masculinity: Comparative Ethnographies. New York: Routledge, 1994.

DESCARTES, R. Meditations on first philosophy. Melbourne: Cambridge University Press, 1996.

DURIE, M. Kaupapa Hauora Maõri: Policies for Maori Health. Paper presented at the Te Ara Ahu Whaka mua, Mãori Health Decade Hui, Te Papa I Ouru Marae, Ohinemutu, Rotorua, 1994.

. Te Mana, Te Kãwanatanga: the politics of Mãori Self-Determination. Auckland: Oxford University Press, 1998.

ESLAND, G. Teaching and learning as the organization of knowledge. In: YOUNG, M. (ed.). Knowledge and control. London: Crowell, Collier, and Macmillian, 1971.

FOUCAULT, M. Discipline and punish. London: Tavistock, 1977.

GOLDING, A. Maori activities in Physical education: part 1. Journal of Physical Education, New Zealand, vol. 17, n. 3, 1959.

HARKER, R.; McCONNOCHIE, K. Education as cultural artifact: studies in Maori and aboriginal education. Palmerston North: Dunmore Press, 1985. 
HARVARD-WILLIAMS, P. Marsden and the New Zeland Mission: Sixteen Letters. Dunedin: University of Otago Press, 1961.

HEGEL, G. The philosophy of history. New York: Colonial Press, 1899.

HOKOWHITU, B. Maori masculinity, post-strucuralism, and the emerging self. New Zealand Sociology, vol. 18, n. 1, 2003.

. The mana Maori - Te Tãtari i ngã Kãrero Parau. Ph.D. thesis, University of Otago, 2002.

HYDE, T. White men can't jump: the polynesianisation of sport. Metro, vol. 67, 1993.

KARETU, T. Tha dance of a Nohle People. Auckland: Reed Books, 1993.

LACLAU, E. New reflections on the revolution of our time. London: Verso, 1990.

MACLEAN, M. Of warriors blokes: the problem of Maori rugby for Pakeha masculinity in New Zealand. In: CHANDLER, T.; NAURIGHT, J. (eds.). Making the rugby world: race, gender, commerce. London: Routledge, 1999, p. 1-26.

MANGAN, J. A. Images for Confidente Control: Stereotypes in Imperial Discourse. In: . (ed.). The Imperial Curriculum: racial images and education in the british colonial experience. London: Routledge, 1993.

MANING, F. Old New Zeland. Christchurch: Capper Whitcombe and Tombs, 1956.

MATHESON, J. So what's the White answer? NZ Rugby World, vol. 47, n. 32, 2001.

MCGEORGE, C. Race, empire and the Maori in the New Zealand primary school curriculum. In: MANGAN, J. A. (ed.). The Imperial Curriculum: racial images and education in the british colonial experience. London: Routledge, 1993. 
METGE, J. In and out of Touch: Whakamaa in Cross Cultural context. Wellington: Victoria University Press, 1986.

MILES, R. Racism. London: Routledge, 1989.

NANDY, A. The intimate enemy. Oxford: Oxford University Press, 1983.

NEW ZEALAND EDUCATION DEPARTMENT, Native Education. Education Gazettem vol. 20, issue 10, 1941.

NEW ZEALAND EDUCATION DEPARTMENT, The School Journal, vol. 2, issue 1, 1908 .

NEW ZEALAND EDUCATION DEPARTMENT, The School Journal, vol. 3, issue 3, 1909.

NEW ZEALAND PHYSICAL EDUCATION SOCIETY, “Titi Torea Poi", New Zealand Journal of Physical Education, vol. 9, 1956.

NIRANJANA, T. Sitting translation: history, post-structuralism, and the colonial context. Berkeley: University of California Press, 1992.

PALMER, F. Maori girls, power, physical education, sport, and play: being Hungus, Hori, and Hoha. Ph. D thesis, University of Otago, 2000.

RAMSAY, P. Maori Schooling. In: HAVILL, S. J.; MITCHELL, D. R. (eds.). Issues in New Zealand Special Education. Auckland: Holder and Stoughton, 1972, p. 68-80.

ROSS, B. Presidente's column: Kia Ora Katou! Journal of Physical Education New Zealand, vol. 31, issue 1, 1998.

ROYDHOUSE, A. P. Thirty years ago, New Zealand Physical Education Society Bulletin, vol. 2, issue 4, 1947.

SAID, E. Orientalism. New York: Vintage books, 1978.

SALMOND, A. The study of traditional Maori society: the state of the art. Journal of the Plynesian Society, vol. 92, n. 318, 1983. 
SHICK, R; DOLAN, R. Masculinity and a man's country in 1998: an interview with Jock Phillips. In: LAW, H. C; DOLAN, J. (eds.). Masculinities in Aotearoal / New Zeland. Palmerston North: Dunmore Press, 1999.

SIMON, J. (ed.). Ngã Kura Mãori: the native schools system, 18671969. Auckland University Press, 1998.

. The place of Schooling in Maori-Pakeha relations. Ph.D. thesis, University of Auckland, 1990.

SKINNER, W. Surf-riding by canoe. Journal of the Polynesian Society, vol. 32, 1923, p. 35-37.

SLATTER, G. On the ball: the centennial book of New Zealand rugby (Christchurch: Whitcombe and Tombs, 1970.

SMITH, B. S. The meeting of Maori and European Cultures and its effects upon the unorganized games of Maori Children. Journal of the Polynesian Society, vol. 60, issue 1/2, 1951.

SMITH, L. T. Decolonizing methodologies: research and indigenous people. London: Zed, 1999.

SMITHELLS, P. Maori rhythm, Education Gazette, vol. 20, 1941.

STOHART, B. A brief history of the Physical Education Advisory service. Wellington: Bob Stohart, 1996.

. A landmark conference: Te hui o te rei kori, New Zealand Journal of Health, Physical Education, and Recreation, vol. 25, issue 2, 1992.

STRONG, T. The problem of educating the Maori. In: JACKSON, P. M. (ed.). Maori and education: on the education of natives in New Zealand und its dependencies. Wellington: Fergunson and Osborn, 1931.

TAIT, S. Advertising, cultural criticism and mythologies of the male body. In: LAW, H. C; DOLAN, J. (eds.). Masculinities in Aotearoal / New Zeland. Palmerston North: Dunmore Press, 1999. 
THOMSON, A. The story of New Zeland: past and present, savage and civilized. Vol. 1. London: John Murray, 1859.

WADE, W. A journey in the Northern Insland of New Zeland. Christchurch: Capper Press, 1997.

WALKER, R. Ka Whawhai Tanu Matou. Auckland: Penguin, 1990.

WARD, M. J. B. The child's geography for school and home tuition. London: John Murray, 1879.

WILKES, C. Narrative of the United States exploring expedition during the years 1838, 1839, 1840, 1841, 1842. Philadelphia: Lea and Blanchard, 1845.

YOUNG, M. E. D. An approach to the study of curricula as socially organized knowledge. In: YOUNG, M. E. D. (ed.). Knowledge and control. London: Collier-Macmillion, 1971.

Recebido em: 15/09/2011

Revisado em: 18/10/2011

Aprovado em: 05/12/2011

Endereço para correspondência

brendan.hokowhitu@otago.ac.nz

Brendan Hokowhitu

School of Maori, Pacific and Indigenous Studies

University of Otago

PO Box 56

Dunedin 9054, New Zealand 